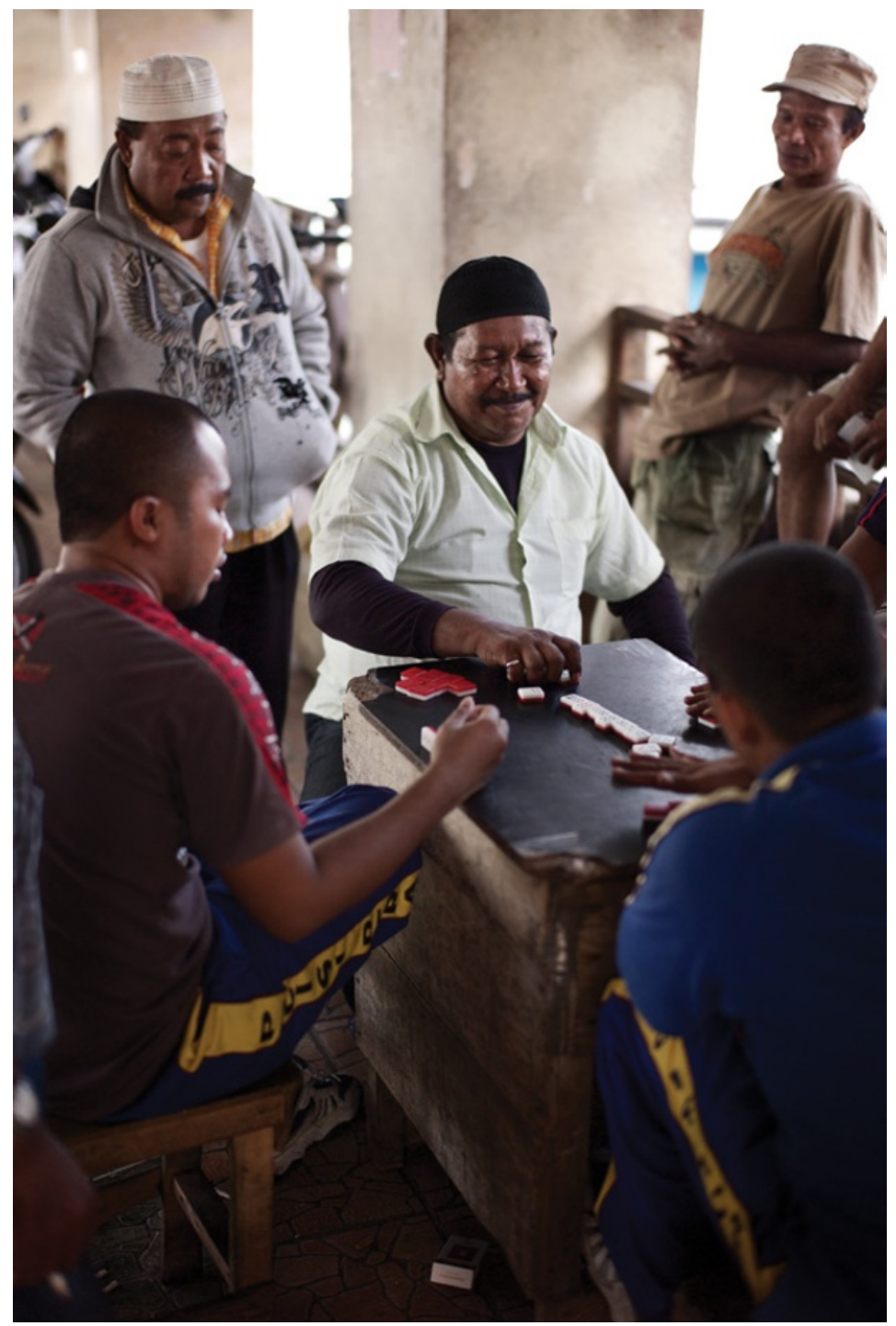

Fig. 6 TERNATE: Dock bosses spend much of the day (and night) at the central pier playing dominos for money, petty sums per point which can nevertheless add up to a tidy amount. Even though gambling is illegal, local police frequently join in the action. Meanwhile, more junior members of the dock gang are allocated actual loading and unloading of boats, from which the bosses reserve a cut. June 2010: photo by S. Chris Brown 


\title{
RESISTING REFORMS: \\ THE PERSISTENCE OF PATRIMONIALISM IN PEKALONGAN'S CONSTRUCTION SECTOR
}

\author{
Amalinda Savirani
}

\section{Introduction}

After the fall of President Suharto and the concomitant economic crisis in 1998, international agencies such as the IMF and the World Bank pressured Indonesia to reform its economy. The control of nepotistic networks over important sectors of the economy had created a form of 'crony capitalism' (Yoshihara 1988) that, it was argued, was hampering Indonesia's competitiveness. Alongside various democratic reforms, Indonesia adopted measures intended to free its economy from the influence of cliques of businessmen and politicians. This chapter discusses the impact of these reforms. Focusing on the construction sector in a middlesized town in Central Java named Pekalongan, it highlights the various ways in which local elites in such towns use their social networks to undermine attempts to make the allotment of construction projects more transparent and impersonal.

Indonesia's economy has since long been characterized by an intense cooperation between politicians, bureaucrats and businessmen, as 'insider' firms were granted privileged access to markets and state contracts in exchange for kickbacks and electoral support. The New Order state was termed patrimonial (Crouch 1979) as political and military elites could reap large benefits by creating business monopolies for their cronies and limiting the competition from 'outsider' firms (Cheung 2005; Beeson 2001). Patron-client relations developed between business entrepreneurs and administrators. Entrepreneurs won business opportunities by performing favours and drumming up electoral support for political leaders. This system not only limited incentives for Indonesian firms to be competitive, but also fuelled social inequalities. The 'Suharto franchise' basically amounted to officials using 'the coercive power of government to impose this "private taxation" on the general public' and to redistribute the revenue to a small elite (McLeod 2011:52). 
Indonesia's monetary crisis and the fall of Suharto provided a strong impetus to end this kolusi between business and politics. Using a discourse centred on 'transparency', 'accountability' and 'good governance', international agencies swooped in to propose measures that were intended to strengthen the capacity of state institutions to implement policies and allocate resources in a more impersonal, rule-bound manner. Government institutions were directed to use open tender processes to award governmental contracts, and the system of certifications was beefed up to monitor the quality and trustworthiness of firms applying for these contracts. A few years after these reforms were implemented, it became apparent that 'predatory elites' had been very successful in circumventing such measures to maintain their lucrative access to state resources. Observers began to criticize the technocratic nature of the 'neo-institutionalist' reforms, arguing that adoption of various regulatory measures did little to address the weaknesses of state institutions and might have even played into the hands of elites who possessed the capacity to manipulate the implementation of state regulations (Hadiz and Robison 2005; Hadiz 2010; Beeson 2001).

This chapter offers a local, up-close evaluation of the impact of these economic reforms by highlighting both the resulting changes and some continuities in the way the construction sector operates in one provincial town. Through ethnographic fieldwork on the functioning of local construction companies in Pekalongan, on the north coast of Central Java, it shows that while local construction firms have lost some of their hold over the process of awarding contracts, the practice of developing strong ties between politicians and contractors has not disappeared. On the contrary, as local firms now face stiffer competition from outside contractors, they have tightened their links with politicians to find ways to keep these competitors out. These practices, this chapter argues, can be particularly successful in middle-sized towns. In a place like Pekalongan the interpersonal networks are sufficiently tight-knit to develop effective control over the tendering process.

\section{Procurement Regimes}

The construction sector in Indonesia has long been highly politicized. The awarding of governmental contracts for building roads or schools proved also to be an effective way to provide jobs to supporters. Provisions were put in place to prioritize small and local firms, and contractors began to 
develop close ties with the ruling Golkar party to maximize their chances of securing new contracts. In line with the corporatist setting of the New Order, the Indonesian builders association Gapensi only had member firms who were willing to prove their loyalty to Golkar (MacIntyre 1991).

As part of the reform agenda adopted after 1998, this interaction between contractors and state officials came under scrutiny. By making the awarding of contracts more transparent and rule-bound, government projects might be made more efficient and less costly - particularly if the common practice of paying a kickback for receiving a contract could be curtailed (World Bank 2001). In 1999 the first bill on procurement activities was adopted, to be followed by several others. ${ }^{1}$ These laws tightened rules for classifying and certifying the firms that were permitted to compete in a government tender process. Construction firms were classified on the basis of their turnover, equipment and personnel, thus limiting the number of firms that could compete for the bigger projects. The certification process was not only intended to limit the capacity of politicians and bureaucrats to manipulate the process on behalf of their client-firms, but also aimed to improve the quality of the work. Companies that performed badly could lose their certification. A board for the development of the construction sector was set up to oversee the certification. With a national office and many regional branches, the Institute for the Development of the Construction Industry (Lembaga Pengembangan Jasa Konstruksi, LPJK) was entrusted with the task of accrediting construction firms. However, particularly many smaller firms felt the LPKJ was biased against them. In 2010 they convinced the politicians to curtail LPKJ's responsibilities. After that the association of construction companies was permitted to certify their own member firms.

A second innovation was that the tender process for awarding a government contract became more open. All tenders (apart from those on the smallest budgets) had to be announced publicly and be open for applications from companies based anywhere in Indonesia. Since the presidential instruction of 2007, an electronic system for announcing and applying to tenders has been set up. The e-procurement system is by now widely used and has, according to Indonesia's anti-corruption body KPK, led to a

\footnotetext{
1 Apart from the enactments of the bill (Law 18/1999), there are at least six implementing regulations, namely Government Regulations $28 / 2000$ on the role of the construction society in the construction sector; 80/2003 on guidelines for the construction sector (amended as 4/2010, and re-amended as 92/2010); and 29/2000 on information required for the procurement activities (amended as 59/2010).
} 
significantly more effective use of state budgets. ${ }^{2}$ Nonetheless, the e-procurement system was still on trial during my fieldwork in Pekalongan. To make the tender process even more transparent, some government agencies started to invite citizens to participate in the evaluation of the bids. $^{3}$ One result has been, for example, that the central government allocation for education within the Special Funding Allocation (Dana Alokasi Khusus, DAK) is now often disbursed through school committees, as I will discuss in more detail below.

\section{Resisting Reform in Pekalongan}

Pekalongan is a medium-sized town of 300,000 inhabitants in Central Java. Most derive their livelihood from trading activities, while many jobs are also related to the public sector. The private sector consists mostly of textile-related industries such as batik, sarong and garments, ranging in scale from home industries to sizeable manufacturing plants. The city used to process fish and produce jasmine tea on a small scale, but both have declined in recent years. After dipping into the red during the Asian crisis of the late 1990s, economic growth in the city of Pekalongan once more reached a healthy $5 \%$ p.a. in 2010. There are at present 95 construction enterprises in Pekalongan, up from 42 in 1998. Most are very small, lacking permanent offices or equipment let alone permanent personnel. The assets of most of these companies do not amount to more than a few million rupiah (a few hundred US dollars). Their most prized assets are their political contacts and their experience. When company directors have to report their assets on official tender forms, they regularly mention their private homes as company assets, in order to qualify for bigger projects. Most of the construction activities commissioned by Pekalongan's local government involve relatively small projects such as local roads, bridges, irrigation channels and ditches. For the bigger projects Pekalongan's companies lack the equipment and capacity. A Jakarta firm was hired to build the local hospital.

More than half of the contractors in Pekalongan today used to work for one of the two big construction firms operating here in the 1980s, CV

2 See 'Mencegah korupsi melalui e-procurement', KPK Jakarta 2007, http://www.kpk .go.id/uploads/rnd/mencegah_korupsi_melalui_eprocurement.pdf (last accessed October 2012).

3 Examples are the water and sanitation procurement programme (PAMSIMAS) and the 'Water Supply and Sanitation for Low Income Communities' projects coordinated by the Ministry of Health. See LP3ES 2007. 
Bersatu and Ikamuda Enterprise. The directors of these two firms, respectively Wabi Baisya and Kamaludin Bachir, developed a proximity to Golkar and the military establishment. This enabled them to monopolize the town's construction activities. Having worked together in these two firms, the current leaders of Pekalongan's construction sector form a relatively tight-knit network.

The reformasi period shook up the construction sector in Pekalongan. As Golkar lost its grip on power, new construction firms could gain access to projects by cultivating contacts with the political parties who emerged after the fall of Golkar. Pekalongan's construction companies can be divided into two groups. On the one hand there are the 'senior' enterprises set up before the fall of Suharto, who are generally still close to politicians and bureaucrats from Golkar. The second, 'junior', group are those firms set up after the fall of Suharto, who benefited from Golkar's weakened grip on power by aligning themselves with new political parties. As the number of firms increased, competition for contracts became more fierce. The builder's association associated with Golkar lost much of its influence as new associations - mostly associated with new political parties - have come up.

This increased competition has not, however, necessarily made the competition for government contracts more transparent. In the following section I will assess the impact of the reforms on the process of allotting government contracts. I will identify three ways through which bureacrats, politicians and construction firms sometimes succeed in circumventing the new regulations on procurement activities to defend their own interests. Firstly, in the context of increased political competition, politicians can ill afford to award government contracts without demanding financial and electoral support in return. As a result, clientelistic practices have hardly subsided. Secondly, as politicians and bureaucrats are sensitive to arguments that local firms should benefit from local-government budgets, they turn a blind eye to the ongoing intimidation the locals practise against outsider firms to discourage them from participating in tender processes. Thirdly, weaknesses of local civil society defeat policy efforts to increase citizen participation, as a lack of knowledge enables local contractors to manipulate the proceedings. I will discuss these observations in turn.

\section{Clientelistic Practices}

Projects are awarded through the involvement of three types of local actors: members of parliament, builders associations and administrators. Once the district government budget has been agreed between the 
Pekalongan local parliament and local-government officers (dinas), the branch chair persons of the various builders associations are summoned and they are informed about upcoming tenders in Pekalongan in the coming year. However, this meeting is only the official start of an open bidding process for these tenders. Informal agreements have usually already been made long before between administrators and politicians on the one hand, and contractors on the other. These agreements generally involve a clientelistic exchange, as builders promise to contribute to election campaigns in exchange for help to secure a government contract. For example, one of my informants, Syukri (40), is a contractor belonging to the second, 'younger', group. In 2008 he financed the campaign for the 2009 legislative election of a candidate from the Golkar party named Sayid. He expected that once Sayid was elected, he would help get him some government projects. The newer contractors mainly focused on developing such ties with politicians, while the 'senior' builders made use of their connections to administrators. The latter do not necessarily offer administrators electoral support, although some of them do cultivate these contacts for launching a political career. Rather, they offer lucrative kickbacks and, occasionally, support to secure a promotion. In this way, politicians often back a different contractor than the administrators. Project allotments take the form of negotiations between them, with the mayor as the final 'referee'.

These actors do not have unlimited freedom to hand the contract to their preferred contractors. They still need to work within the existing procurement rules, which for example do not allow them to award a contract to a more costly bidder. All tenders are published in the newspapers, and the bids have to be evaluated on the basis of more or less open criteria. Yet it is at this point that administrators and politicians can manipulate proceedings in favour of their preferred company. For each tender process, specifications ('spek' is the commonly used term in Pekalongan) are formulated to detail what the bidding company needs to deliver. By including very particular specifications, the competition can be narrowed considerably. For example, when the local government needed new computers, those involved in the tender process specified that they desired only one particular computer brand - of which 'their man' was the only distributor in Central Java. In this way the inclusion of very specific requirements in the 'spek' enables politicians and administrators to favour 'their' companies. In this way the new procurement rules do curtail the freedom of local elites - as they have to be much more transparent in 
awarding contracts - but enough loopholes remain to give them at least some grip over the tendering process.

After the fall of the New Order, both the number of contractors and of political parties have multiplied. Clientelistic networks organized around a few powerful patrons within the Golkar party have atrophied, while multiple smaller cliques have sprung up that now compete to develop access to state resources. Indonesia's democratization process has given politicians more influence in the process of awarding government contracts. Election results have therefore become of vital importance to the construction sector. After the fall of Suharto in 1998, Golkar lost considerable influence and, consequently, its associated builder association Gapensi lost its grip on the process of allotting contracts. New competing associations emerged to profit from this situation. Nevertheless, in 2005 a Golkar candidate managed, with the support of local Gapensi members, to become Pekalongan's mayor. That meant a major membership boost for Gapensi, which was once again the place to be. As they had by far the largest membership (more than $70 \%$ of all Pekalongan's contruction firms were Gapensi members) they claimed the right to distribute most projects among their own members.

Such observations suggest that old clientelistic practices die hard in Pekalongan. Despite the implementation of reforms that aimed to make procedures more impersonal and rule-bound, the nurturing of clientelistic ties between builders, politicians and administrators is still common practice. One reason for the persistence of this practice is that they strengthen ties that are essential to protect local firms against increased competition from outside firms. I will discuss this further below.

\section{Pekalongan Money for Pekalongan People}

The reforms in the tendering process have in principle opened the bidding process for government contracts to companies from any part of Indonesia. The Pekalongan construction sector was ill-prepared to face this competition. In the first years after 2006, when the open tender system started, more than half the projects were awarded to companies from outside of Pekalongan. ${ }^{4}$ This led to protests from the local construction firms, and their arguments were well received by local politicians. As the

\footnotetext{
${ }^{4}$ Interview with the head of the tender committee, 'Mr A'.
} 
head of Pekalongan's parliament, Salahudin (37), said, 'uang orang Pekalongan harus untuk orang Pekalongan', or, 'Pekalongan money should be for Pekalongan people'. Local elites became convinced that the strict implementation of an open tendering process would imply a loss of livelihood for those working in construction.

A solution was devised to prevent this. An informal kesepakatan, or understanding, developed between bureaucrats, politicians and builders. The tender process would proceed in a normal fashion, but ways would be sought to discourage outsiders from applying. As usual, the tender would be announced in the newspapers, and after submission of the proposals the tender committee would verify the proposals before reaching its final decision. Part of the process was a 'screening' of participating firms on their suitability. It was at this stage that subtle and not-so-subtle techniques were applied to pressure outside firms to withdraw their bid. Local firms would hire local preman (strong men) to approach representatives from outside firms and, if needed, intimidate them and so prevent them from submitting or pursuing their bid. As one builder said to me, his 'friends' were ready with a knife if the outside participants were reluctant to withdraw. 'But it hardly ever resulted in real violence', he added, implying that intimidation usually had the desired effect. This practice is so well known that during my fieldwork everyone I met, from the head of Pekalongan parliament, through departmental heads of offices, the tender committee, heads of associations and the contractors themselves, all discussed it openly, sometimes even without my asking about it. Yet my informants were aware that this practice contravened national regulation. An executive of the builders association Gapensi told me he did not want 'Jakarta people' to find out, as 'it would have a serious impact if they did'.

Ironically, in this respect the reforms in the construction sector seem to have had an adverse affect. Measures that were intended to break clientelistic ties and to open the bidding process have drawn local contractors, politicians and administrators together into tighter collusive bonds. They recognized their shared interest in keeping outsiders out and in preventing punitive measures from 'Jakarta'.

\section{The Capture of School Committees}

Part of the reform of the procurement process was the involvement of civil society in the awarding of government contracts. However, an 
examination of the actual functioning of one of these civil-society organizations reveals how and why such organizations cannot always live up to the expectation of being a watchdog against corruption and nepotism. School committees have been set up all over Indonesia over the last ten years to assist local schools with such activities as devising new curricula and setting up and maintaining facilities. Before the committees, the school principal had been in charge of these activities, but now the principal merely acts as a member of the committee, together with parents and prominent social leaders. ${ }^{5}$ There have been school committees before ${ }^{6}$ but the committees proposed in Law 2003 on the education system increased the role and responsibilities of parents. The school committees became particularly important after 2006. In that year the Special Funding Allocation scheme (DAK), a key financing instrument in regional autonomy, began funding construction projects in the education sector. The Ministry of Education decreed that only the school committee could propose construction activities at school. The committees suddenly became very important in the process of acquiring and spending money for school facilities. The World Bank had advised this role for school committees ${ }^{7}$ because it believed that if parents as stakeholders are involved in proposing and supervising projects, they will have strong incentives to award contracts to reliable and efficient contractors.

In practice this supervisory role is undermined both by a lack of capacity and by the persistence of clientelistic practices. Neny $(38)$ is principal of one of the 132 private elementary schools in Pekalongen. At first she did not pay much attention to the composition of the school committee. She told me that when the head of the education office in Pekalongan ordered her to submit the names of members of her school committee, she had no idea whom to contact. She randomly asked some people she knew, such as her neighbours, close friends and family members. At first she cared little about the background of the members of the committee and saw it as a mere bureaucratic requirement: 'I was busy taking care of my students and other affairs at my school.' But gradually she realized it was important to have people with political contacts and lobbying skills on

\footnotetext{
5 www.mandikdasmen.depdiknas.go.id/docs/dok_14.pdf (accessed 26 June 2010).

6 Earlier school committees were called POMG (Persatuan Orang Tua Murid dan Guru) or Teachers and Parents Group. Before that, the name was $\mathrm{BP}_{3}$ (Badan Pembantu Penyelenggaraan Pendidikan).

7 Personal communication on 1 September 2009 with Dr TNE, who was a World Bank consultant involved in drafting the new policies on school committees in Indonesia, and who wishes to remain anonymous.
} 
the committee. In order to acquire state funds for school facilities, the school has to send proposals to the Department of Education within the district government. This department does not have the final say in the evaluation of these proposals, but issues a recommendation to the regional parliament, which takes the final decision. It is at this stage that the school needs to have relations with the constructors and their political contacts to ensure that its proposal is successful.

School committees without strong political connections stand less chance of state funding. When Neny heard that her school could submit proposals to renovate her school, she began to regret that she did not have someone with a construction background on her committee. She asked a friend of her brother, who was a local contractor, to join the committee. 'It was such a good opportunity for my school to renovate the building. As a private school, it is so hard to mobilize funds for these expenses. I could not let this opportunity pass by just because our school committee had no one with a technical background in construction'. She needed someone with contacts in parliament and the Education Department - precisely the contacts that contractors cultivate professionally. At the same time, however, committees that rely on local contractors to secure state budgets lose their capacity to critically supervise the process of awarding a contract. Once the budget is approved, the contract will go to the contractor who helped to secure the budget.

Baiqi is a 40-year-old constructor. He can help us understand how the supervisory role of the school committee is undermined in practice. He has been active since a young age in the youth organization Garda Bangsa, which belongs to the large Islamic association Nadhlatul Ulama (NU). NU has numerous schools. Baiqi's membership of Garda Bangsa has yielded abundant contacts with principals of NU schools. Many have asked him to join their school committees. As ordinary members did not know how to prepare a DAK funding proposal, Baiqi was often asked to use his expertise in dealing with government to do so. Each one of his first four proposals was successful. Other schools began to seek him out as well. At present he sits on the committees of no less than 12 schools, which enables him to secure the construction projects from all these schools. Lack of knowledge among ordinary committee members makes them dependent on those who do know; and the need is not simply for technical knowledge. As proposals are not awarded in a straightforward, rule-bound manner, the committees need someone with good political contacts. These dependencies force school committees to go along with the clientelistic practices that they were supposed to prevent. 


\section{Conclusion: The Construction Sector after Reformasi}

This chapter has discussed the challenges of making the process of awarding government contracts more transparent and less corruption-prone. After the fall of Suharto, various measures were adopted to end the longstanding collusion between contractors and state officials. Ethnographic fieldwork on the construction sector in one provincial town has revealed that the local impacts of these reforms have at times been contrary to their intention. In some respects the reforms did have the desired effects. The procurement process was wrestled from the control of a few powerful patrons. In the early years of the reforms, the construction sector seemed to have become more open as many contracts were awarded to contractors from outside of Pekalongan, suggesting that local connections were not all-important in the process of awarding government contracts. But this chapter has shown that local clientelistic networks proved to have considerable resilience. They regained their capacity to undermine the reform measures.

The social networks in a medium-sized town such as Pekalongan are relatively tightly knit compared to larger cities. These have enabled local contractors, administrators and politicians to devise ways of regaining control over the procurement process. I discussed three interrelated strategies. Firstly, I highlighted that the reforms failed to curb prevailing clientelistic practices. In their quest for campaign budgets and electoral support, local politicians could ill afford to award government contracts without forcing contractors to return the favour. So, while the appearance of an open bidding process was maintained, contractors made deals with politicians and administrators to increase their chances of winning a contract. These clientelistic deals were facilitated by the fact that all the local actors had a shared interest in preventing state budgets from going to outside actors. The second strategy I discussed was the intimidation of outside contractors to enhance the opportunities for local contractors. With the knowledge of local administrators, local preman are hired to discourage outsiders from submitting or pursuing their bid. Thirdly, I discussed why policy provisions to involve civil society could not change these practices. As members of school committees needed people with skills and political contacts to gain access to state budgets, they have become dependent on the very actors - contractors and politicians - whose actions they were supposed to supervise.

Taken together, this chapter underlines earlier critiques (for instance, Hadiz 2010) of the inadequacy of policy measures adopted after the fall of 
the New Order due to their technocratic nature. Measures to change the functioning of state bureaucracies had often been adopted at the behest of multilateral organizations like the World Bank. By wishing away or, at least, paying insufficient attention to the broader (clientelistic) political context in which these reforms are carried out, the measures often end up having little effect, and sometimes even make things worse. The livelihoods of the actors involved - local contractors, but also politicians and administrators - depend on finding ways to circumvent or undermine the implementation of reform measures. As a result, the measures end up having the unintended effect of strengthening rather than weakening clientelistic exchanges of favours between provincial town actors who know each other well. 